\title{
ANXA8L1 wt Allele
}

National Cancer Institute

\section{Source}

National Cancer Institute. ANXA8L1 wt Allele. NCI Thesaurus. Code C124956.

Human ANXA8L1 wild-type allele is located in the vicinity of 10q11.22 and is approximately $162 \mathrm{~kb}$ in length. This allele, which encodes annexin A8-like protein 1, plays a role in calcium-mediated phospholipid binding. 